\title{
Trend and status of air quality at three different monitoring stations in the Klang Valley, Malaysia
}

\author{
Siti Zawiyah Azmi • Mohd Talib Latif • \\ Aida Shafawati Ismail • Liew Juneng • \\ Abdul Aziz Jemain
}

Received: 4 July 2009 / Accepted: 20 August 2009 /Published online: 28 October 2009

(C) The Author(s) 2009. This article is published with open access at Springerlink.com

\begin{abstract}
Over the last decades, the development of the Klang Valley (Malaysia), as an urban commercial and industrial area, has elevated the risk of atmospheric pollutions. There are several significant sources of air pollutants which vary depending on the background of the location they originate from. The aim of this study is to determine the trend and status of air quality and their correlation with the meteorological factors at different air quality monitoring stations in the Klang Valley. The data of five major air pollutants $\left(\mathrm{PM}_{10}, \mathrm{CO}, \mathrm{SO}_{2}, \mathrm{O}_{3}, \mathrm{NO}_{2}\right)$ were recorded at the Alam Sekitar Sdn Bhd (ASMA) monitoring stations in the Klang Valley, namely Petaling Jaya (S1), Shah Alam (S2) and Gombak (S3). The data from these three stations were compared with the data recorded at Jerantut, Pahang (B), a background station established by the Malaysian Department of Environment. Results show that the concentrations of $\mathrm{CO}, \mathrm{NO}_{2}$ and $\mathrm{SO}_{2}$ are higher at Petaling Jaya (S1) which is due to influence of heavy traffic. The concentrations of $\mathrm{PM}_{10}$ and $\mathrm{O}_{3}$, however, are predominantly related to regional tropical factors, such as the influence of biomass burning and of ultra violet radiation from sunlight. They can, though, also be influenced by local sources. There are relatively stronger inter-pollutant correlations at the stations of Gombak and Shah Alam, and the results also suggest that heavy traffic flow induces high
\end{abstract}

S. Z. Azmi • A. S. Ismail • A. A. Jemain

School of Mathematical Sciences, Faculty of Science

and Technology, Universiti Kebangsaan Malaysia,

43600 Bangi, Selangor, Malaysia

M. T. Latif $(\triangle) \cdot$ L. Juneng

School of Environmental and Natural Resource Sciences, Faculty

of Science and Technology, Universiti Kebangsaan Malaysia,

43600 Bangi, Selangor, Malaysia

e-mail: talib@ukm.my concentrations of $\mathrm{PM}_{10}, \mathrm{CO}, \mathrm{NO}_{2}$ and $\mathrm{SO}_{2}$ at the three sampling stations. Additionally, meteorological factors, particularly the ambient temperature and wind speed, may influence the concentration of $\mathrm{PM}_{10}$ in the atmosphere.

Keyword Air quality monitoring stations · Atmospheric pollutants · Statistical analysis $\cdot$ Meteorological parameters $\mathrm{PM}_{10} \mathrm{CO} \mathrm{SO} \mathrm{O}_{3} \mathrm{NO}_{2}$

\section{Introduction}

Urban air pollution, with its long- and short-term impacts on human health, well-being and the environment, has been a widely recognised problem over the last 50 years (Gurjar et al. 2008; Ozden et al. 2008). The clear phenomenon of rural to urban migration has brought as a consequence greater emissions into the atmosphere, which have predominantly been produced by the increase in traffic (Baldasano et al. 2003; Chin 1996). In addition, the rapid growth of urbanisation and industrialisation where the progressive expansion of suburbs into closer proximity with industrial plants in certain areas has led to the problem of air pollution becoming an increasingly important issue (Fenger 1999; Molina and Molina 2004). Besides deleterious effects on human health, air pollution can negatively impact ecosystems, materials, buildings, works of art, vegetation and visibility (Ilyas et al. 2009; Mage et al. 1996; RigaKarandinos and Saitanis, 2005).

Results on land use and the level of compliance from previous studies show that severe problems in air quality status in the Malaysian Peninsular only exist in highly urbanised areas. This is particularly true with respect to dust fall-out, suspended particulate matter and lead in the ambient air along congested roadsides. These problems 
are largely attributed to motor vehicles emissions (Awang et al. 2000). The major sources of air pollution in Malaysia, notably in urban areas are: motor vehicles (mobile sources), industrial and power plants (stationary sources) and open burning (Afroz et al. 2003). According to the Malaysian Department of the Environment (DOE 1996), motor vehicles contributed $82 \%$, power stations $9 \%$, industrial fuel burning $5 \%$, industrial production processes $3 \%$, domestic and commercial furnaces $0.2 \%$ and open burning at solid waste disposal sites $0.8 \%$ to the total of air emission load in the Malaysian Peninsular.

The monitoring of air pollution based on several atmospheric pollutants is common in most countries including Malaysia (Baldasano et al. 2003). These monitoring studies are of particular importance if air quality management efforts are to be improved, long-term air quality trends detected, the possible sources observed and located and the effectiveness of air quality control regulations increased (Ozden et al. 2008). In line with findings in most other countries, the main pollutants recorded at the monitoring stations used in Malaysia are: particulate matter $\left(\mathrm{PM}_{10}\right)$, nitrogen dioxide $\left(\mathrm{NO}_{2}\right)$, sulphur dioxide $\left(\mathrm{SO}_{2}\right)$, carbon monoxide (CO) and ozone $\left(\mathrm{O}_{3}\right)$ (Awang et al. 2000).

The Klang Valley is a basin located in the southwestern part of the Malaysian Peninsular, surrounded by highlands exceeding 1,500 $\mathrm{m}$ altitude to the east and by the Straits of Malacca to the west (Abas and Simoneit 1996; Omar et al. 2002). Due to its location and as one of the most developed areas following rapid urbanisation, population growth and industrial activities, the Klang Valley is constantly exposed to the problem of air quality (Afroz et al. 2007; Rashid and Griffiths 1995; Rashid and Rahmalan 1993; Rashid 1993). This study has been conducted at three different air monitoring stations in the Klang Valley, namely Petaling Jaya, Shah Alam and Gombak, which are located at three different backgrounds and aim to determine the trend, status and possible sources of these five major air pollutants at different stations in the designated area.

\section{Methodology}

Location of sampling stations

The stations used in this study were located in the Klang Valley, Malaysia. The Klang Valley is an area in Malaysia which comprises Kuala Lumpur and its suburbs and adjoining cities and towns in the state of Selangor. The Klang Valley is considered to be the heartland of Malaysia's industry and commerce and was recorded as having a total population of over four million in 2004. In the most recent census, the population in this area had expanded to 4.7 million (DOS 2006).
The Petaling Jaya air monitoring station $\left({\mathrm{N} 03^{\circ}}^{\circ} 06.612^{\prime}\right.$, E101 ${ }^{\circ}$ 42.274'; S1) is located at Sri Petaling Primary School, Petaling Jaya; Selangor. This sampling station is the nearest station to Kuala Lumpur's city centre and is surrounded by industries, residential and commercial areas and consequently, congested roads. The Shah Alam air monitoring station $\left(\mathrm{N}^{\circ} 3^{\circ} 06.287^{\prime}, \mathrm{E}^{\circ} 01^{\circ} 33.368^{\prime}\right.$; S2) is located at Taman Tun Dr Ismail Primary School (TTDI) Jaya, Shah Alam, Selangor. This station is located in a residential area. However, whilst it is near to major roads, the traffic density is lower compared with Petaling Jaya and usually, only significant during the morning and late afternoon rush hours. The next air monitoring station is Gombak (N03 ${ }^{\circ} 15.702^{\prime}, \mathrm{E}_{101^{\circ}}$ 39.103'; S3), which is located at the Water Resource Department, Gombak (Fig. 1). This station is also in a residential area and is surrounded with major roads which experience heavy traffic particularly during the morning rush hour.

The last air quality monitoring station is in Jerantut, Pahang (N03 ${ }^{\circ} 58.238^{\prime}, \mathrm{E} 102^{\circ} 20.863^{\prime}$; B). This station is in fact a background station established by the Malaysian Department of Environment. This monitoring station is located at the Malaysian Meterological Deparment at Batu Embun, Jerantut, Pahang in the middle of the Malaysian Peninsular (Fig. 1). Natural forest, open burning, soil dust and a low number of motor vehicles are expected to contribute to air quality status at this monitoring station.

\section{Air quality data}

The air quality data used for this analysis were obtained from the Air Quality Division of the Department of the Environment, Malaysia, (DOE) through long-term monitoring by a private company, Alam Sekitar Sdn Bhd (ASMA). The air pollutant parameters used in these studies were particulate matter with a diameter size of below $10 \mu \mathrm{m}$ $\left(\mathrm{PM}_{10}\right)$, carbon monoxide $(\mathrm{CO})$, sulphur dioxide $\left(\mathrm{SO}_{2}\right)$, nitrogen dioxide $\left(\mathrm{NO}_{2}\right)$ and ozone $\left(\mathrm{O}_{3}\right)$. In addition, meteorological parameters, such as: wind speed, temperature, UV radiation and humidity were also recorded at the stations. The overall air quality data used in this study was collected between January 1997 and December 2006, with the exception of data from the Shah Alam station (S2) where the air monitoring station started operating after July 1997. In the case of The Petaling Jaya Station (S1), data for $\mathrm{O}_{3}$ and $\mathrm{CO}$ has only been recorded since April 2003 (Table 1).

\section{Missing data}

The "nearest neighbour method" has been used to impute missing data. This method for imputation is considered to be the simplest scheme available in the S-PLUS FinMetrics 
Fig. 1 A geographical map of the sampling stations located in Selangor, Malaysia

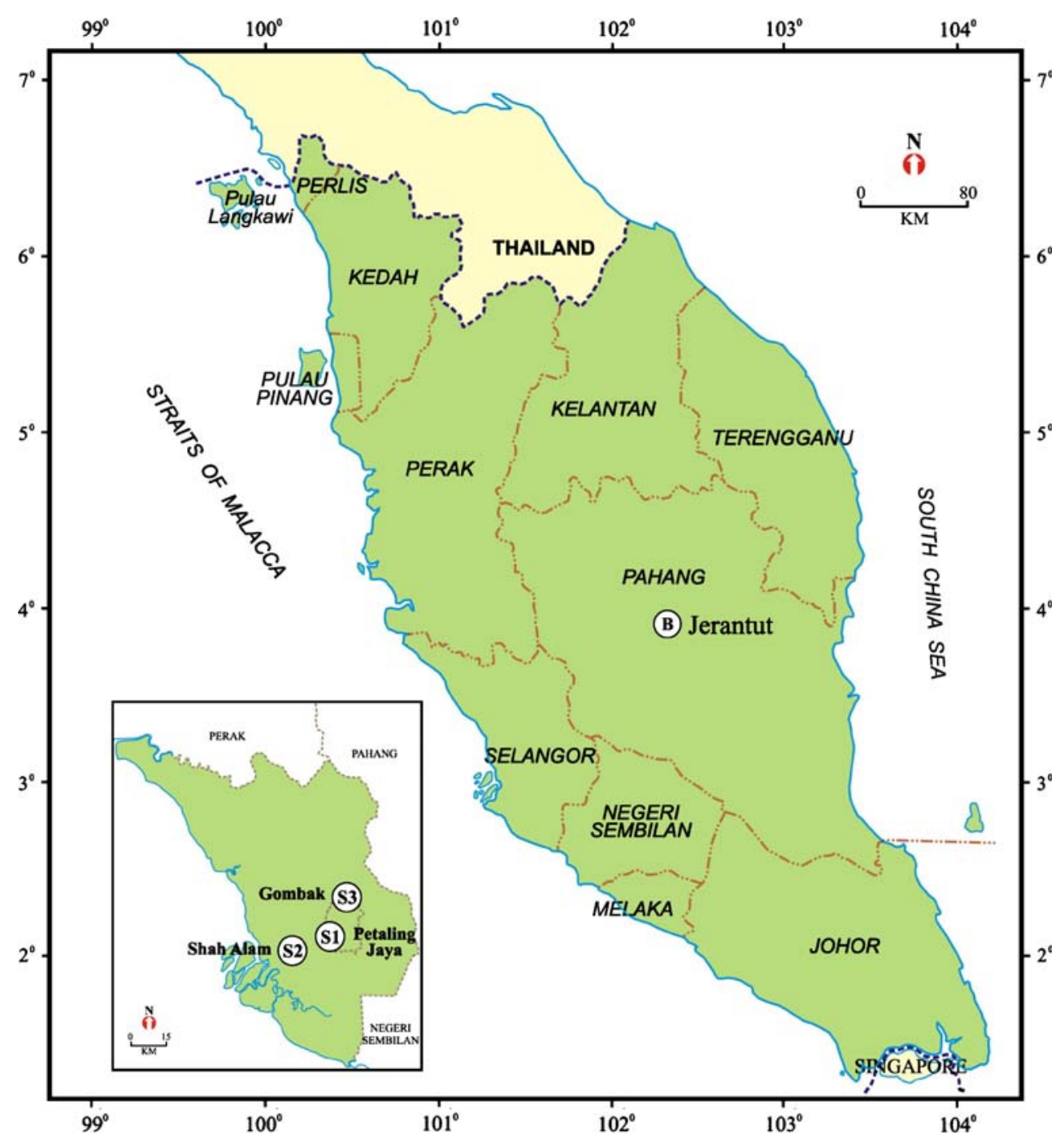

module in that the endpoints of the gaps are used as estimates for all the missing values (Eq. 1).

$\mathrm{y}=\mathrm{y}_{1}$ if $\mathrm{x} \leq \mathrm{x}_{1}+\left(\mathrm{x}_{2}-\mathrm{x}_{1}\right) / 2$,

$\mathrm{y}=\mathrm{y}_{2}$ if $\mathrm{x}>\mathrm{x}_{1}+\left(\mathrm{x}_{2}-\mathrm{x}_{1}\right) / 2$,

Where $y$ is the interpolant, $x$ is time point of the interpolant, $y_{1}$ and $x_{1}$ are the coordinates of the starting point of the gap and $y_{2}$ and $x_{2}$ are the coordinates of the endpoint of the gap. The data that were missing will be interpolated through the nearest neighbour value available using S-PLUS (Junninen et al. 2004).

\section{Statistical analysis}

In order to compare the concentration air pollutants between stations, several statistical analyses were conducted to determine the distribution of air pollutants' concentrations using the Normal P-P Plot, the Normal Q-Q Plot and the One-Sample Kolmogorov-Smirnov test. Analysis of variance with the additional use of the Bonferroni test will be used if the data show a normal distribution. The KruskalWallis test will be used if the data are not in a normal distribution. The Pearson correlation was conducted to determine the relationship between different air pollutants at each station as well as the connection between $\mathrm{PM}_{10}$ concentration and meteorological factors, such as: temperature, wind speed and humidity. Data collected at each sampling station in the year 2006, was used. Both analyses of variance and correlation analysis were conducted using the Statistical Package for Social Sciences (SPSS).

\section{Trajectory analysis}

The backward trajectories of atmospheric pollutants were determined by using the Hybrid Single Particle Lagrangian Integrated Trajectory (HYSPLIT) Model introduced by the National Oceanographic and Atmospheric Administration through the website http://www.arl.noaa.gov/ready.html at different monsoon seasons in Malaysia. The trajectories to these three main stations had been developed for $48 \mathrm{~h}$ on 
Table 1 Overall data on air quality at the different stations in the Klang Valley with Jerantut as the background station

\begin{tabular}{|c|c|c|c|c|c|c|c|c|c|c|}
\hline Parameters & $\begin{array}{l}\text { Averaging } \\
\text { time }\end{array}$ & Station & Number & $\begin{array}{l}\text { Started } \\
\text { date }\end{array}$ & Average & Median & $\begin{array}{l}\text { Standard } \\
\text { deviation }\end{array}$ & Minimum & Maximum & RMAQG \\
\hline \multirow[t]{4}{*}{$\mathrm{PM}_{10}\left(\mathrm{ugm}^{-3}\right)$} & \multirow[t]{4}{*}{$24 \mathrm{~h}$} & $\mathrm{~S} 1$ & 120 & Jan 1997 & 58.10 & 55.00 & 20.10 & 27.00 & 172.00 & \multirow[t]{4}{*}{150} \\
\hline & & $\mathrm{S} 2$ & 114 & Jul 1997 & 54.84 & 51.00 & 22.99 & 22.00 & 150.00 & \\
\hline & & S3 & 120 & Jan 1997 & 56.41 & 53.00 & 23.60 & 30.00 & 218.00 & \\
\hline & & B & 118 & Jan 1997 & 38.64 & 37.00 & 16.24 & 17.00 & 152.00 & \\
\hline \multirow[t]{4}{*}{$\mathrm{CO}$ (ppm) } & \multirow[t]{4}{*}{$1 \mathrm{~h}$} & $\mathrm{~S} 1$ & 45 & Apr 2003 & 1.853 & 1.860 & 0.256 & 1.420 & 2.340 & \multirow[t]{4}{*}{30} \\
\hline & & S2 & 113 & Jul 1997 & 1.002 & 0.970 & 0.314 & 0.490 & 2.200 & \\
\hline & & S3 & 119 & Jan 1997 & 0.953 & 0.890 & 0.227 & 0.630 & 1.180 & \\
\hline & & B & 119 & Jan 1997 & 0.323 & 0.320 & 0.103 & 0.000 & 0.680 & \\
\hline \multirow[t]{4}{*}{$\mathrm{NO}_{2}(\mathrm{ppm})$} & \multirow[t]{4}{*}{$1 \mathrm{~h}$} & S1 & 120 & Jan 1997 & 0.033 & 0.033 & 0.005 & 0.024 & 0.051 & \multirow[t]{4}{*}{0.17} \\
\hline & & S2 & 114 & Jul 1997 & 0.019 & 0.019 & 0.004 & 0.002 & 0.031 & \\
\hline & & S3 & 120 & Jan 1997 & 0.017 & 0.017 & 0.004 & 0.009 & 0.025 & \\
\hline & & B & 119 & Jan 1997 & 0.002 & 0.002 & 0.001 & 0.000 & 0.004 & \\
\hline \multirow[t]{4}{*}{$\mathrm{SO}_{2}(\mathrm{ppm})$} & \multirow[t]{4}{*}{$1 \mathrm{~h}$} & $\mathrm{~S} 1$ & 120 & Jan 1997 & 0.008 & 0.008 & 0.003 & 0.004 & 0.015 & \multirow[t]{4}{*}{0.13} \\
\hline & & $\mathrm{S} 2$ & 114 & Jul 1997 & 0.007 & 0.006 & 0.003 & 0.003 & 0.018 & \\
\hline & & $\mathrm{S} 3$ & 120 & Jan 1997 & 0.003 & 0.003 & 0.001 & 0.000 & 0.007 & \\
\hline & & B & 117 & Jan 1997 & 0.001 & 0.001 & 0.001 & 0.000 & 0.005 & \\
\hline \multirow[t]{4}{*}{$\mathrm{O}_{3}(\mathrm{ppm})$} & \multirow[t]{4}{*}{$1 \mathrm{~h}$} & $\mathrm{~S} 1$ & 45 & Apr 2003 & 0.014 & 0.014 & 0.004 & 0.009 & 0.024 & \multirow[t]{4}{*}{0.10} \\
\hline & & $\mathrm{S} 2$ & 114 & Jul 1997 & 0.020 & 0.019 & 0.004 & 0.012 & 0.035 & \\
\hline & & $\mathrm{S} 3$ & 119 & Jan 1997 & 0.016 & 0.016 & 0.003 & 0.010 & 0.028 & \\
\hline & & B & 118 & Jan 1997 & 0.011 & 0.011 & 0.004 & 0.004 & 0.027 & \\
\hline
\end{tabular}

RMAQG $=$ Recommended Malaysian Air Quality Guideline

1st of January 2006 (North East Monsoon), 1st of April 2006 (Inter monsoon), 1st of August 2006 (South West Monsoon) and 1st of October 2006 (Inter-monsoon).

\section{Result and discussion}

Long-term record of air quality data

The compilation of the data from the three sampling stations in the Klang Valley (Petaling Jaya, Shah Alam and Gombak) and their comparison to the background station (Jerantut) is summarised in Table 1. The averaged concentration of $\mathrm{PM}_{10}$ recorded at Petaling Jaya, Shah Alam and Gombak are $58.10{\mu \mathrm{gm}^{-3}}^{-3}$ (27.00$\left.172.00 \mu \mathrm{gm}^{-3}\right), 54.84 \mu \mathrm{gm}^{-3}\left(22.00-150.00 \mu \mathrm{gm}^{-3}\right)$ and

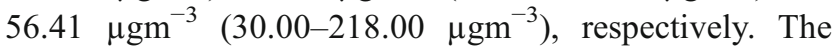
averaged concentration of $\mathrm{PM}_{10}$ recorded at these three stations was found to differ significantly between the stations $(p<0.01$; Table 2$)$ and was far below the the value suggested by the Recommeded Malaysian Air Quality Guideline (RMAQG) for the $24 \mathrm{~h}$ averaged concentration $\left(150 \mu^{-3}{ }^{-3}\right)$. However, these values are remarkably higher

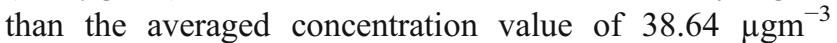
(17.00-152.00 ${\mu \mathrm{gm}^{-3}}^{-3}$ recorded at Jerantut, Pahang, which was used as the background station (Station B). Neverthe- less, the averaged concentration of $\mathrm{PM}_{10}$ at these three

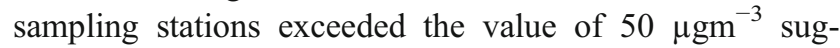
gested by the European Comission for $\mathrm{PM}_{10}$. Urban background, due to the number of motor vehicles, industries and level of street dust, is expected to contribute to the amount of suspended particulate matter in the atmosphere at these three stations compared with the background area.

The long-term records of $\mathrm{PM}_{10}$ data as shown in Fig. 2 indicated that the concentration of $\mathrm{PM}_{10}$ was found to be higher during certain months in that particular year due to the haze episode e.g. in August-September, 1997, where

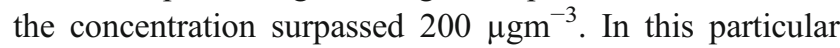
episode, almost all air quality monitoring stations in the Malaysian Peninsular, including the Jerantut stations, were affected by the transboundary sources of biomass burning around Southeast Asia, especially from Sumatra, Indonesia as shown in Fig. 2. The haze event in 1997 was the worst ever experienced by the country. Short-term observations using continuous monitoring systems during the haze episodes clearly showed that suspended particulate matter was the major air pollutant during this period and was transboundary in nature as a result of large-scale forest fires in parts of Sumatra (Awang et al. 2001; Keywood et al. 2003; Mott et al. 2005; Radojevic and Hassan 1999).

The averaged concentration of all gases is still under the threshold limit by the Recommended Malaysian Air 
Table 2 Analysis of variance of diffent air pollutants

\begin{tabular}{lllllll}
\hline Parameter & Comparison & $\begin{array}{l}\text { Sum of } \\
\text { squares }\end{array}$ & $\begin{array}{l}\text { Degree of } \\
\text { freedom }(\mathrm{df})\end{array}$ & $\begin{array}{l}\text { Mean } \\
\text { square }\end{array}$ & F-Value & Significant \\
\hline $\mathrm{PM}_{10}$ & Between groups & 28793.584 & 3 & 9597.861 & 21.921 & .000 \\
& Within groups & 204906.28 & 468 & 437.834 & & \\
& Total & 233699.86 & 471 & & & \\
$\mathrm{NO}_{2}$ & Between Groups & .058 & 3 & .019 & 1417.428 & .000 \\
& Within Groups & .006 & 469 & .000 & & \\
& Total & .064 & 472 & & & \\
$\mathrm{O}_{3}$ & Between Groups & .004 & 3 & .001 & 97.273 & .000 \\
& Within Groups & .006 & 392 & .000 & & \\
& Total & .010 & 395 & & & \\
$\mathrm{CO}^{*}$ & Between Groups & 81.908 & 3 & 27.303 & 504.150 & \\
& Within Groups & 21.229 & 392 & .054 & & .000 \\
& Total & 103.137 & 395 & & & \\
$\mathrm{SO}_{2}$ & Between Groups & .004 & 3 & .001 & 277.244 & \\
& Within Groups & .002 & 467 & .000 & & \\
& Total & .006 & 470 & & & \\
& & & & & & \\
\end{tabular}

Quality Guideline (RMAQG) for ambient air (Table 1). There are significant differences between the gas concentrations recorded at the various stations. This suggests that the local surroundings influence the concentration of gases at each station (Table 2). The mean and range of $\mathrm{CO}$ found resulted in it being the most prevalent gas recorded in the atmosphere at all three stations followed by $\mathrm{NO}_{2}, \mathrm{O}_{3}$ and $\mathrm{SO}_{2}$. $\mathrm{CO}$ was clearly recorded at a higher concentration at Petaling Jaya with a mean value of $1.853 \mathrm{ppm}(1.420$ $2.340 \mathrm{ppm}$ ) compared with Shah Alam (1.002 ppm, 0.490$2.200 \mathrm{pmm}$ ) and Gombak (0.953 ppm, 0.630-1.180 ppm). The other gas which was also recorded at a very high concentration at Petaling Jaya is $\mathrm{NO}_{2}$, which had an average concentration of $0.033 \mathrm{ppm}(0.024-0.051 \mathrm{ppm})$ compared with Shah Alam (0.019 ppm, 0.002-0.031 ppm) and Gombak (0.017 ppm, 0.009-0.025 ppm). The concentration of these two gases is due to the emissions from motor vehicles as indicated by several other studies e.g. Dor et al. (1995), Mayer (1999), Janssen et al. (2001) and Morawska et al. (2002).

Even though there are clear differences between the $\mathrm{SO}_{2}$ and $\mathrm{O}_{3}$ levels recorded in the Klang Valley and Jerantut (the background station), among the three different stations within the Klang Valley, no significant differences are indicated (Table 1). $\mathrm{SO}_{2}$ is usually the result of industrial activities (Pereira et al. 2007), but at these three stations, the main source of $\mathrm{SO}_{2}$ is expected to be from motor vehicles predominantly diesel-engined trucks and buses. $\mathrm{SO}_{2}$ was found to be at high levels during haze episodes. This would be expected due to the composition of the sulphur compound, particularly from biomass burning as cited by Clairac et al. (1988). The reduction of sulphur in petrol and diesel was found to contribute to the amount of $\mathrm{SO}_{2}$ in the atmosphere, more notiably in urban and suburban areas. $\mathrm{O}_{3}$ is a secondary gas produced by the interaction of hydrocarbon, oxides of nitrogen and sunlight (Atkinson 2000). Based on the results, the level of $\mathrm{O}_{3}$ at these three stations can be seen to be much more closely related to the intensity of sunlight and the contribution of other precursors rather than nitrogen dioxide and hydrocarbon from motor vehicles. This can be argued due to its low concentration at Petaling Jaya (S1), in comparison to Shah Alam (S2) and Gombak (S3). A high concentration of NO is expected to be produced by motor vehicles in the urban areas; this has the capability to interact with $\mathrm{O}_{3}$ to form $\mathrm{NO}_{2}$ in the atmosphere.

\section{Daily trends}

The results from Fig. 3 show that there is a clear peak of concentration for $\mathrm{PM}_{10}, \mathrm{CO}, \mathrm{NO}_{2}$ and $\mathrm{SO}_{2}$ at all three stations when compared with the background station (Jerantut). The daily concentration of all the pollutants was also clearly recorded as being at the highest concentration at Petaling Jaya. Traffic congestion, particularly during the morning peak between 7:00 am-9:00 am, led to the higher amount of $\mathrm{CO}$ in the the atmosphere. The peak of $\mathrm{CO}$ concentration recorded at Shah Alam and Gombak decreased significantly towards the afternoon while the peak of $\mathrm{CO}$ concentration recorded at Petaling Jaya declined only slightly. This phenomenon is considered to correlate directly with the number of motor vehicles at the two stations (Shah Alam and Gombak), which are located in residential areas, and at these particular times, the number of motor vehicles increased significantly as people were going to work and children to school. In the latter part of the afternoon, $\mathrm{CO}$ 

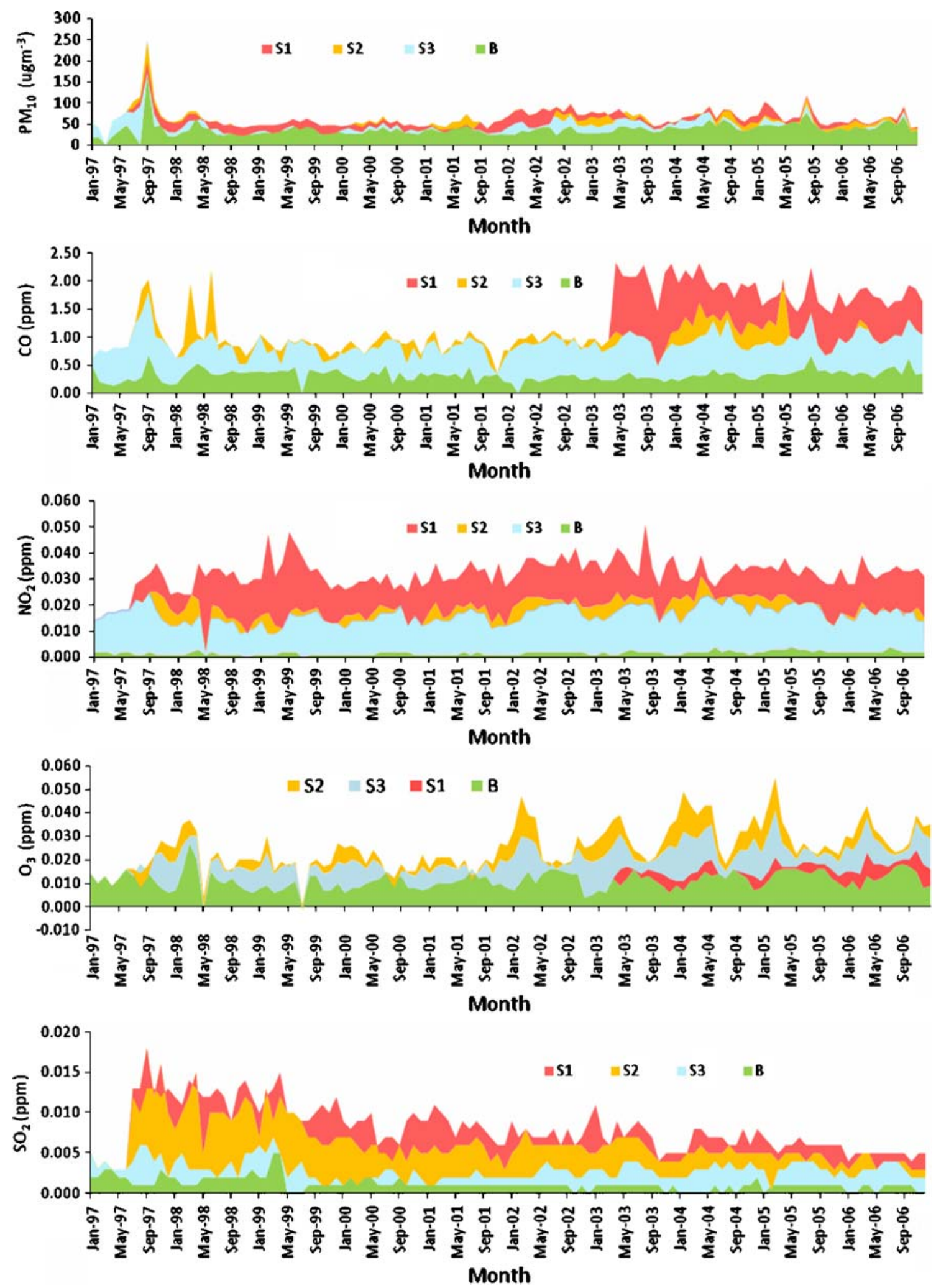

Fig. 2 Monthly trends for air quality in the Klang Valley 

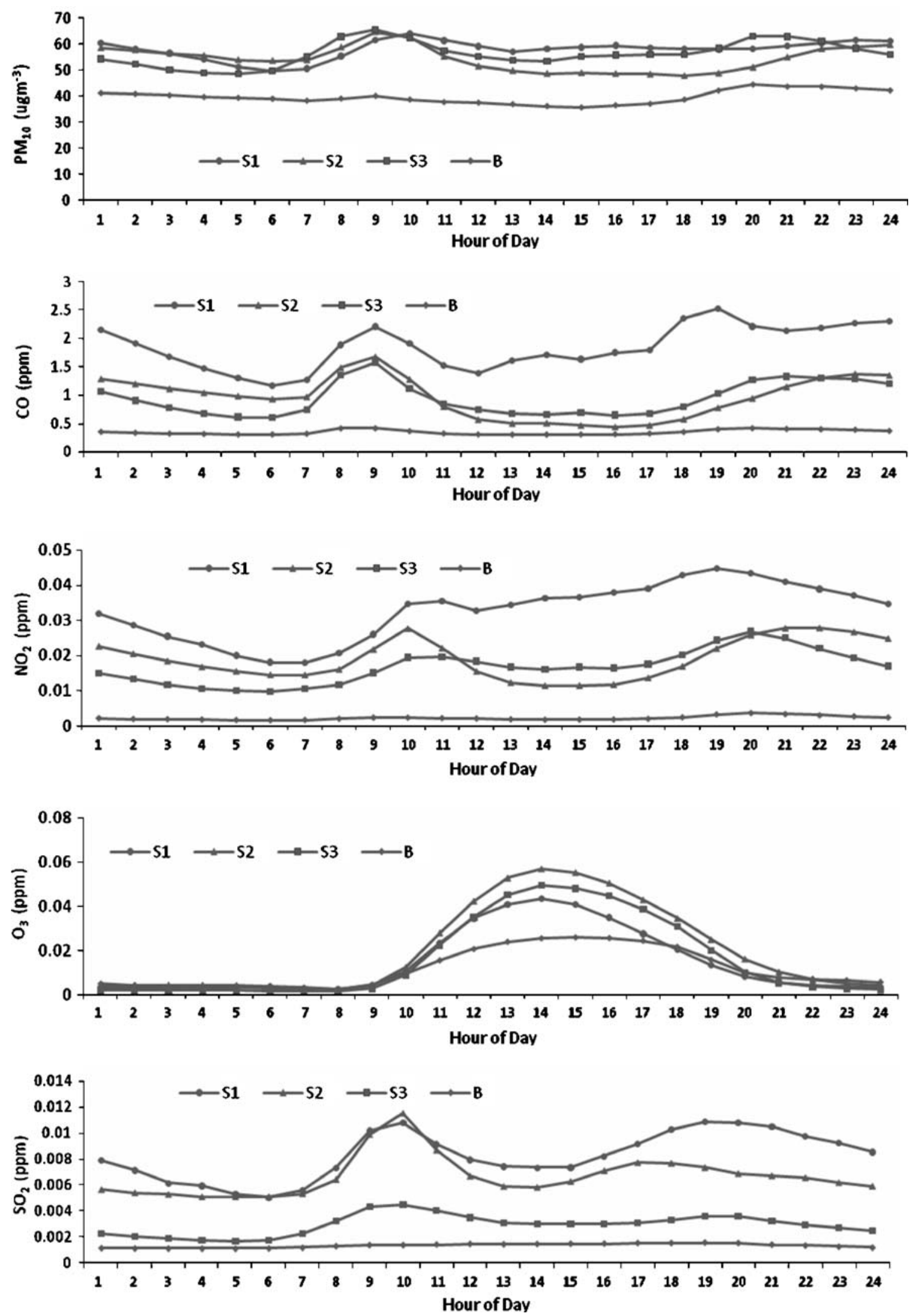

Fig. 3 Hourly trends of air quality in the Klang Valley 
concentration peaked from 5:00 pm in line with the evening rush hour when people started returning home from work. The late evening peak can also be attributed to meteorological conditions, particularly atmospheric stability and wind speed (Afroz et al. 2003; Awang et al. 2000).

The other two parameters which show the same daily pattern as $\mathrm{CO}$ are $\mathrm{NO}_{2}$ and $\mathrm{SO}_{2} . \mathrm{NO}_{2}$ is usually produced by motor vehicles, and its concentration was found to stable from midday towards the late afternoon. This trend was also recorded at Gombak but at lower values of $\mathrm{NO}_{2}$ concentration. Nevertheless, the trend of $\mathrm{NO}_{2}$ recorded at Shah Alam indicates a significant peak of $\mathrm{NO}_{2}$ concentration at around 10:00 am before it decreased towards midday and then increased again in the early evening. These fluctuations give an indication of the movement of motor vehicles around Shah Alam's residential areas where most of the residents travel by motor vehicles on the outskirts of Shah Alam. The level of traffic during working hours was expected to be low and at the same time to lower the concentration of $\mathrm{NO}_{2}$ in the atmosphere. For $\mathrm{SO}_{2}$, the daily trend at all three locations was nearly the same, and the results were considered to be influenced by motor vehicles emissions, particularly from buses, lorries and trucks near the monitoring stations themselves.

Fig. 2 shows $\mathrm{O}_{3}$ trends and demonstrates that the formation of this gas is influenced by sunlight through photochemical reactions (Atkinson 2000; Sillman 1999). The concentration of it at all three stations as well as the background station was found to increase in the morning and return to its earlier and lower concentration at 9:00 pm in the evening (Fig. 3). The highest concentration of ozone was recorded around 2:00 pm in the afternoon, whilst the highest concentration of ozone during peak hours was recorded at Shah Alam, followed by Gombak and Petaling Jaya. These results did not reflect the results of the other gases which were recorded at the highest level in Petaling Jaya. Due to the lower concentration of $\mathrm{NO}_{2}$ in Shah Alam (0.002-0.031 ppm) compared with Petaling Jaya (0.024$0.51 \mathrm{ppm})$, it is considered that other factors, such as volatile organice carbon (VOC), probably contributed to ozone formation in this location. This result is supported by Paoleti (2009), who found higher a concentration of ozone in suburban areas compared with urban areas. These were considered to be most likely due to the complex interactions between the production of VOC and the ability of several species, such as: NO, to remove ozone from the atmosphere (Sillman 1999). Moreover, meteorological factors such the local temperature at the sampling stations would also have the ability to increase the concentration of ozone in the atmosphere as indicated by Geddes et al. (2009).

Correlation between air pollutants and meteorological factors

The correlations beween atmospheric pollutants at all stations are shown in Table 3. Petaling Jaya station only recorded a positive significant correlation $(p<0.01)$ between $\mathrm{CO}$ and $\mathrm{SO}_{2}$. Nevertheless, all parameters recorded
Table 3 Correlation ( $r$ value) between parameters at the sampling stations

\footnotetext{
** Correlation is significant at the 0.01 level (2-tailed)

* Correlation is significant at the 0.05 level (2-tailed)
}

\begin{tabular}{|c|c|c|c|c|c|c|}
\hline Stations & Parameters & $\mathrm{PM}_{10}$ & $\mathrm{CO}$ & $\mathrm{NO}_{2}$ & $\mathrm{O}_{3}$ & $\mathrm{SO}_{2}$ \\
\hline \multirow[t]{5}{*}{ Petaling Jaya (S1) } & $\mathrm{PM}_{10}$ & 1 & & & & \\
\hline & $\mathrm{CO}$ & -0.016 & 1 & & & \\
\hline & $\mathrm{NO}_{2}$ & 0.152 & 0.065 & 1 & & \\
\hline & $\mathrm{O}_{3}$ & 0.068 & $-0.490 * *$ & 0.035 & 1 & \\
\hline & $\mathrm{SO}_{2}$ & 0.117 & $0.595 * *$ & -0.077 & $-0.337 * *$ & 1 \\
\hline \multirow[t]{5}{*}{ Shah Alam (S2) } & $\mathrm{PM}_{10}$ & 1 & & & & \\
\hline & $\mathrm{CO}$ & $0.590 * *$ & 1 & & & \\
\hline & $\mathrm{NO}_{2}$ & $0.649 * *$ & $0.549 * *$ & 1 & & \\
\hline & $\mathrm{O}_{3}$ & $0.343^{* *}$ & $0.323 * *$ & 0.147 & 1 & \\
\hline & $\mathrm{SO}_{2}$ & 0.127 & $0.220^{*}$ & -0.111 & -0.152 & 1 \\
\hline \multirow[t]{5}{*}{ Gombak (S3) } & $\mathrm{PM}_{10}$ & 1 & & & & \\
\hline & $\mathrm{CO}$ & $0.505 * *$ & 1 & & & \\
\hline & $\mathrm{NO}_{2}$ & $0.523 * *$ & $0.625 * *$ & 1 & & \\
\hline & $\mathrm{O}_{3}$ & $0.472 * *$ & $0.440 * *$ & $0.441 * *$ & 1 & \\
\hline & $\mathrm{SO}_{2}$ & $0.352 * *$ & $0.343 * *$ & $0.195 *$ & $0.207^{*}$ & 1 \\
\hline \multirow[t]{5}{*}{ Jerantut (B) } & $\mathrm{PM}_{10}$ & 1 & & & & \\
\hline & $\mathrm{CO}$ & $0.611 * *$ & 1 & & & \\
\hline & $\mathrm{NO}_{2}$ & $0.424 * *$ & $0.267 * *$ & 1 & & \\
\hline & $\mathrm{O}_{3}$ & $0.417 * *$ & $0.391 * *$ & $0.530 * *$ & 1 & \\
\hline & $\mathrm{SO}_{2}$ & $-0.226^{*}$ & 0.054 & -0.131 & -0.138 & 1 \\
\hline
\end{tabular}


Table 4 Overall data on air quality at the different stations in the Klang Valley with Jerantut as the background station

nd $=$ no data available

\begin{tabular}{clllllll}
\hline Parameters & Station & Number & Average & Median & $\begin{array}{l}\text { Standard } \\
\text { deviation }\end{array}$ & Minimum & Maximum \\
\hline Temperature & S1 & 365 & 27.9 & 27.9 & 1.203 & 21.2 & 39.0 \\
(deg C) & S2 & 365 & 27.8 & 27.9 & 1.125 & 21.7 & 38.4 \\
& S3 & 365 & 26.4 & 26.4 & 0.859 & 20.3 & 35.6 \\
& B & 335 & 25.9 & 25.9 & 1.193 & 20.0 & 38.6 \\
Wind Sped & S1 & 365 & 3.3 & 3.2 & 0.730 & 0.7 & 13.5 \\
(km/hr) & S2 & 365 & 4.5 & 4.7 & 1.265 & 0.5 & 17.7 \\
& S3 & 334 & 2.8 & 2.7 & 0.662 & 0.9 & 13.4 \\
& B & 365 & 3.3 & 3.3 & 0.490 & 0.8 & 14.7 \\
UVB(J/m $/ \mathrm{hr})$ & S1 & nd & nd & nd & nd & nd & nd \\
& S2 & 244 & 175 & 161 & 76.743 & 0 & 1257 \\
& S3 & 120 & 162 & 165 & 47.436 & 0 & 1184 \\
& B & 365 & 156 & 156 & 40.363 & 0 & 1016 \\
Humidity (\%) & S1 & 365 & 74.38 & 74.95 & 5.400 & 36.1 & 92.2 \\
& S2 & 335 & 78.08 & 78.202 & 5.695 & 35 & 98.6 \\
& S3 & 306 & 77.94 & 78.40 & 3.844 & 24 & 99.7 \\
& B & 365 & 81.96 & 81.31 & 4.723 & 31.6 & 99.6 \\
\hline
\end{tabular}

in Gombak were found to be correlated to each other. The strongest significant correlation recorded at this station was between $\mathrm{CO}$ and $\mathrm{NO}_{2}(r=0.625, p<0.01)$. This correlation pattern indicates that there were the same sources of atmospheric pollutants recorded in Gombak and Petaling Jaya. Petaling Jaya itself, is located in a congested, urban and industrial area, which would lead to the existence of atmospheric pollutants from various sources in comparison to Gombak, which is more influenced by the movement of motor vehicles. Shah Alam appears to be in the middle of these two stations with the concentration of $\mathrm{PM}_{10}, \mathrm{CO}$ and $\mathrm{NO}_{2}$ correlated between each other.

The meteorological data recorded at each air monitoring station are summarised in Table 4 . The average temperature for all stations was in the range of 25.9 to $27.9^{\circ} \mathrm{C}$, while wind speed, UVB and humidity were in the range of 2.8 to $4.5 \mathrm{~km} / \mathrm{h}, 156$ to $175 \mathrm{~J} / \mathrm{m}^{2} / \mathrm{h}$ and 74.38 to $81.96 \%$, respectively (Table 4). These meteorological conditions
Fig. 4 Correlation between $\mathrm{PM}_{10}$ and meteorology
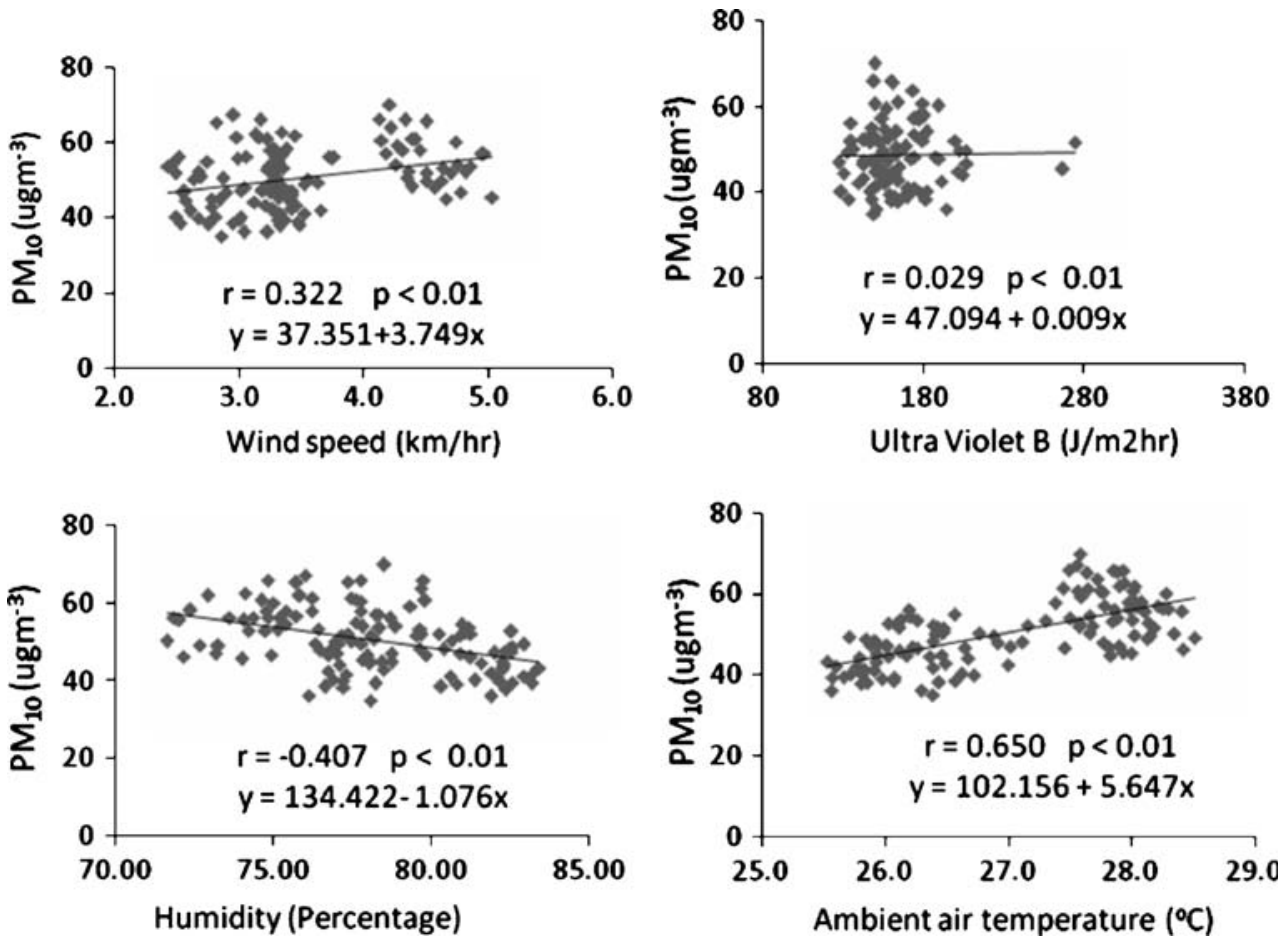
NOAA HYSPLIT MODEL

Backward trajectories ending at 1200 UTC 01 Jan 06 GDAS Meteorological Data

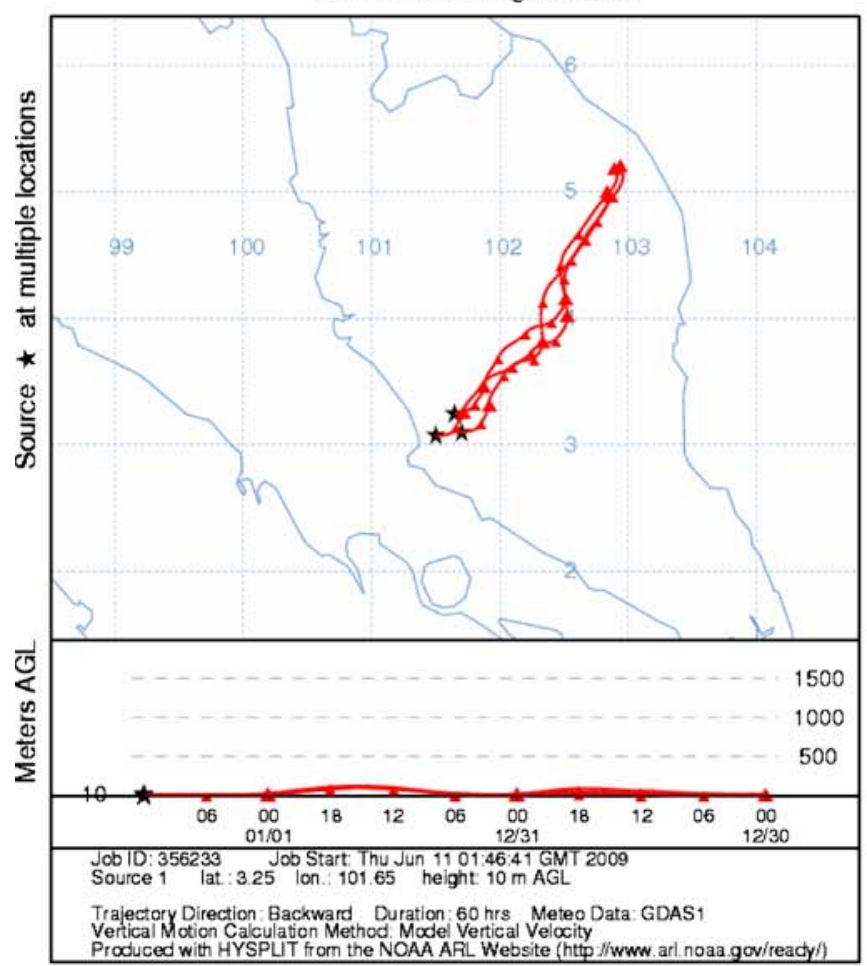

January 2006

NOAA HYSPLIT MODEL

Backward trajectories ending at 1200 UTC 01 Aug 06 GDAS Meteorological Data

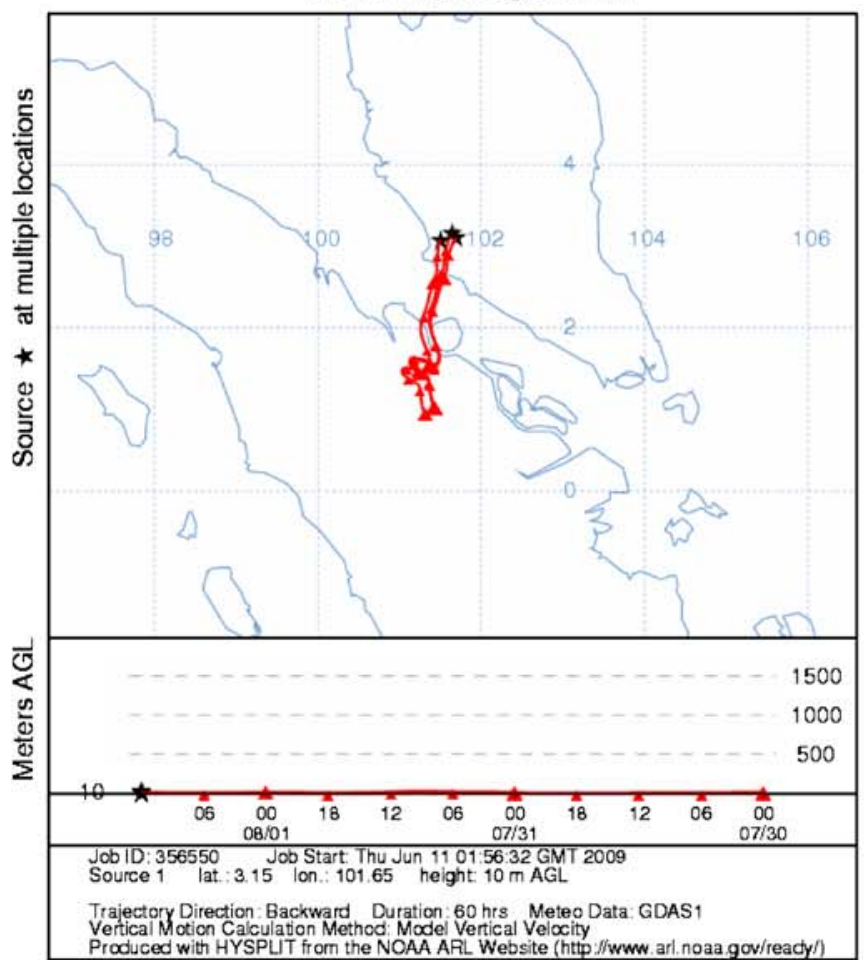

August 2006
NOAA HYSPLIT MODEL

Backward trajectories ending at 1200 UTC 01 Apr 06 GDAS Meteorological Data

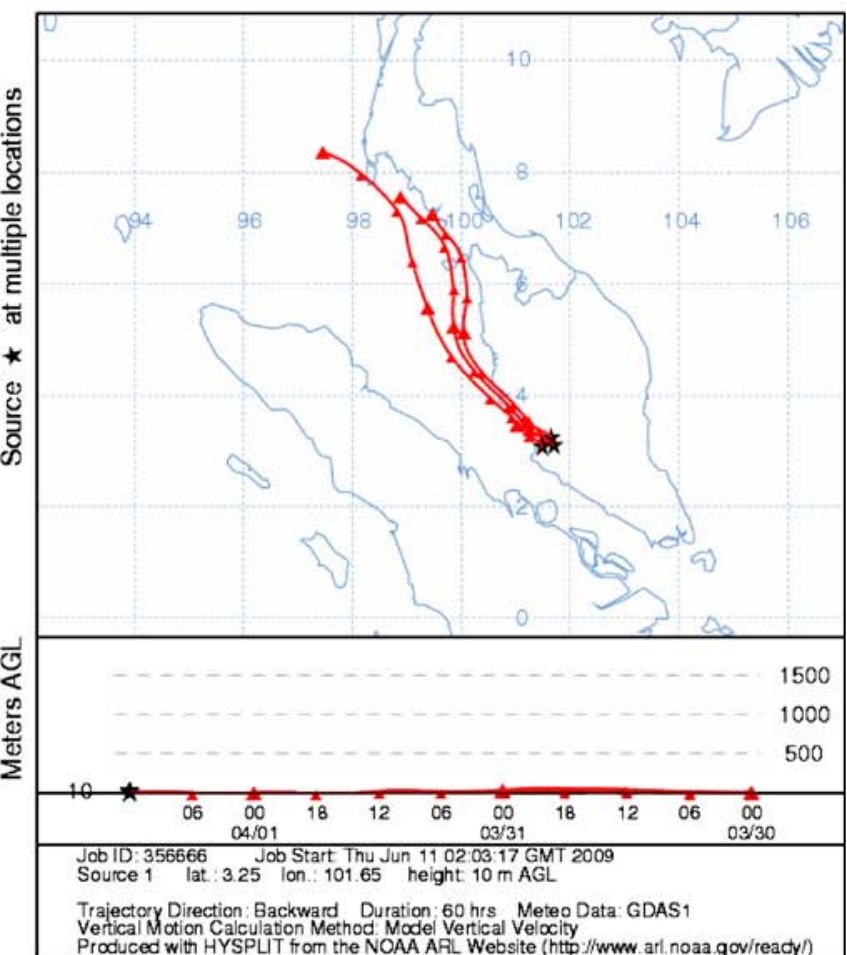

April 2006

NOAA HYSPLIT MODEL

Backward trajectories ending at 1200 UTC 01 Oct 06 GDAS Meteorological Data

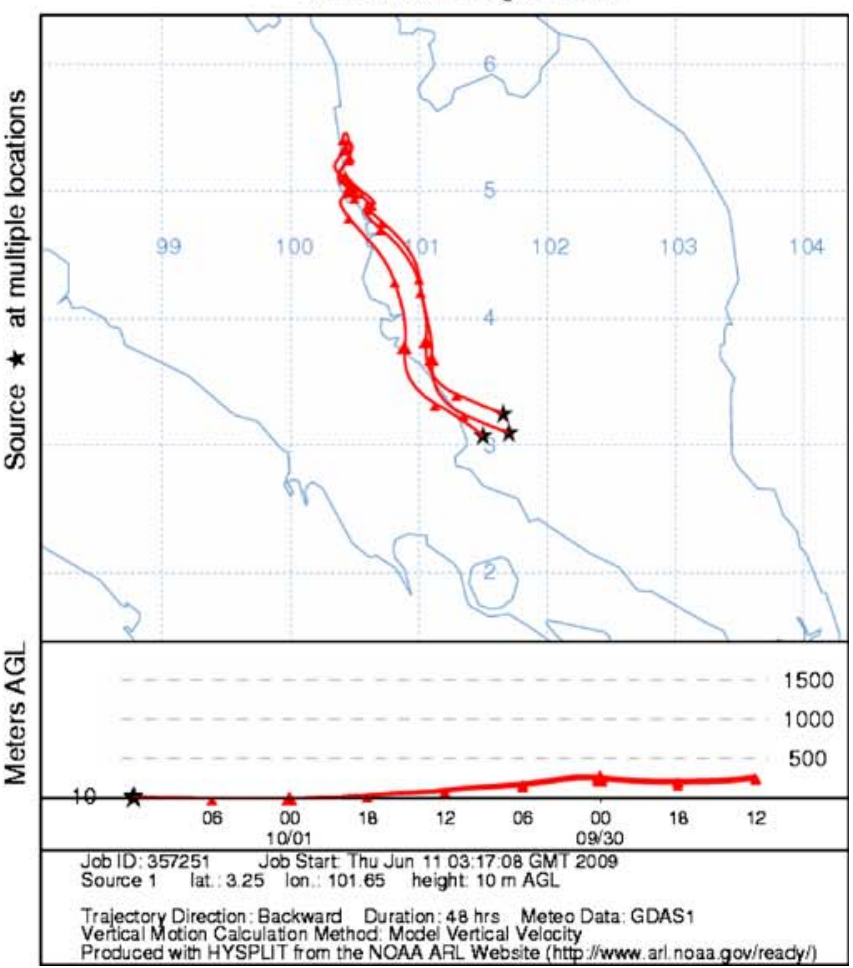

October 2006 
Fig. 5 Backward trajectories to the selected stations in the Klang Valley in different seasons

are typical for a tropical environment. Correlation between the most significant air pollutants $\left(\mathrm{PM}_{10}\right)$ and meteorological factors (Fig. 4) indicates that the $\mathrm{PM}_{10}$ concentration has a significant positive correlation with ambient temperature $(r=0.650, p<0.01)$. A high temperature in the tropics usually increases the quantity of biomass burning and the evaporation of materials e.g. soil dust from the earth's surface. High humidity is commonly related to the number of rain occasions, and this reduces the number of particles due to the wash-out processes of the atmospheric aerosols in the atmosphere. Therefore, there is a negative correlation between humidity and $\mathrm{PM}_{10}$ in ambient air. Other factors such as wind speed and UV radiation were found to slightly influence the concentration of particulate matter in the atmosphere in the study areas.

The southwest monsoon occurs between June and September each year and is usually associated with the generation of haze episodes in the Malaysian Peninsular as a result of biomass burning from Sumatra, Indonesia. Back trajectory analysis using the HYSPLIT Model (Fig. 5) shows that the southwest monsoon wind from Sumatra can arrive at all three monitoring stations within $48 \mathrm{~h}$. During the intermonsoon season (October and April) the wind systems are large north-westerlies as is shown by trajectories using the HYSPLIT Model. The north-east monsoon, which occurs annually between November and March, is usually connected to the wet season and therefore does not contribute to the amount of anthropogenic sources, particularly from biomass burning, coming from east part of the Malaysian Peninsular.

\section{Conclusion}

The results from this study show that the averaged concentration of all atmospheric pollutants recorded at Petaling Jaya, Shah Alam and Gombak are under the permissible value recommended by the Malaysian Department of Environment. However, the pollution levels are distinctively higher when compared with the background station (Jerantut) used in the study. While the levels of $\mathrm{PM}_{10}$ and $\mathrm{O}_{3}$ correlate more closely with the transboundary sources, due to photochemical processes, the averaged concentration of other parameters is influenced more by the number of motor vehicles near the monitoring stations. The high concentration of ozone recorded at Gombak and Shah Alam is intriguing and warrants further investigation. Meteorological factors particularly sunlight and the ambient temperature are expected to be associated with the concentration of ozone and suspended particulate matter.
The temperature and wind direction, more notiably from the south-west monsoon (as is indicated by the HYSPLIT Model), can also influence the concentration of suspended particulate matter in the atmosphere. This matter is more often than not, the result of biomass burning in Sumatra, Indonesia. Based on the results of this study, it would be prudent and timely for the associated authorising bodies in Malaysia to begin strategizing and formulating an effective plan to reduce the emissions from motor vehicles and other anthropogenic sources. The effect of sunlight on primary air pollutants and the contribution of volatile organic carbon to the ozone concentration in the atmosphere also needs to be researched and identified.

Acknowledgements The authors would like to thank Universiti Kebangsaan Malaysia for Research University Grant (UKM-GUPASPL-07-05-140 and UKM-GUP-ASPL-07-05-138), and the Malaysian Department of Environment (DOE) for air quality data. The authors also gratefully acknowledge the NOAA Air Resources Laboratory (ARL) for the provision of the HYSPLIT transport and dispersion model and/or READY website (http://www.arl.noaa.gov/ ready.html) as used in this publication.

Open Access This article is distributed under the terms of the Creative Commons Attribution Noncommercial License which permits any noncommercial use, distribution, and reproduction in any medium, provided the original author(s) and source are credited.

\section{References}

Abas MRB, Simoneit BRT (1996) Composition of extractable organic matter of air particles from Malaysia: initial study. Atmos Environ 30:2779-2793. doi:10.1016/1352-2310(95)00336-3

Afroz R, Hassan MN, Awang M, Ibrahim NA (2007) Benefits of air quality improvement in Klang Valley Malaysia. Intern J Environ Pollut 30:119-136. doi:10.1504/IJEP.2007.014507

Afroz R, Hassan MN, Ibrahim NA (2003) Review of air pollution and health impacts in Malaysia. Environ Res 92:71-77. doi:10.1016/ S0013-9351(02)00059-2

Atkinson R (2000) Atmospheric chemistry of VOCs and NO(x). Atmos Environ 34:2063-2101. doi:10.1016/S1352-2310(99)00460-4

Awang MB, Jaafar AB, Abdullah AM, Ismail MB, Hassan MN, Abdullah R, Johan S, Noor H (2000) Air quality in Malaysia: Impacts, management issues and future challenges. Respirol 5:183-196. doi:10.1046/j.1440-1843.2000.00248.x

Awang MB, Jaafar AB, Abdullah AM, Ismail MB, Hassan MN, Abdullah R, Johan S, Noor H (2001) Air quality in Malaysia: Impacts, management issues and future challenges. Off J Asian Pacific Soc Respirol 5:183-196

Baldasano JM, Valera E, Jiménez P (2003) Air quality data from large cities. Sci Total Environ 307:141-165. doi:10.1016/S0048-9697 (02)00537-5

Chin ATH (1996) Containing air pollution and traffic congestion: Transport policy and the environment in Singapore. Atmos Environ 30:787-801. doi:10.1016/1352-2310(95)00173-5

Clairac B, Delmas R, Cross B, Cachier H, Buat-Menard P, Servant J (1988) Formation and chemical composition of atmospheric aerosols in an equatorial forest area. J Atmos Chem 6:301-322 
DOE (1996) Environment quality report, 1995. Department of Environment, Ministry of Science, Technology and Environment, Malaysia, Kuala Lumpur

Dor F, Le Moullec Y, Festy B (1995) Exposure of city residents to carbon monoxide and monocyclic aromatic hydrocarbons during commuting trips in the Paris metropolitan area. J Air Waste Manage Assoc 45:103-110

DOS (2006) Basic population characteristics by administrative districts. Department of Statistics, Kuala Lumpur

Fenger J (1999) Urban Air Quality. Atmos Environ 29:4877-4900. doi:10.1016/S1352-2310(99)00290-3

Geddes JA, Murphy JG, Wang DK (2009) Long term changes in nitrogen oxides and volatile organic compounds in Toronto and the challenges facing local ozone control. Atmos Environ 43:3407-3415. doi:10.1016/j.atmosenv.2009.03.053

Gurjar BR, Butler TM, Lawrence MG, Lelieveld J (2008) Evaluation of emissions and air quality in megacities. Atmos Environ 42:1593-1606. doi:10.1016/j.atmosenv.2007.10.048

Ilyas SZ, Khattak AI, Nasir SM, Qurashi T, Durrani R (2009). Air pollution assessment in urban areas and its impact on human health in the city of Quetta, Pakistan. Clean Technol Environ Policy: 1-9. doi:10.1007/s10098-009-0209-4

Janssen NAH, Van Vliet PHN, Aarts F, Harssema H, Brunekreef B (2001) Assessment of exposure to traffic-related air pollution of children attending schools near motorways. Atmos Environ 35:3875-3884. doi:10.1016/S1352-2310(01)00144-3

Junninen H, Niska H, Tuppurainen K, Ruuskanen J, Kolehmainen M (2004) Methods for imputation of missing values in air quality data sets. Atmos Environ 38:2895-2907. doi:10.1016/j.atmosenv.2004.02.026

Keywood MD, Ayers GP, Gras JL, Boers R, Leong CP (2003) Haze in the Klang Valley of Malaysia. Atmos Chem Phys Discuss 3:615-653

Mage D, Ozolins G, Peterson P, Webster A, Orthofer R, Vandeweerd V, Gwynne M (1996) Urban air pollution in megacities of the world. Atmos Environ 30:681-686. doi:10.1016/1352-2310(95) 00219-7

Mayer H (1999) Air pollution in cities. Atmos Environ 33:4029-4037. doi:10.1016/S1352-2310(99)00144-2

Molina MJ, Molina LT (2004) Megacities and atmospheric pollution. J Air Waste Manage Assoc 54:644-680
Morawska L, Jayaratne ER, Mengersen K, Jamriska M, Thomas S (2002) Differences in airborne particle and gaseous concentrations in urban air between weekdays and weekends. Atmos Environ 36:4375-4383. doi:10.1016/S1352-2310(02)00337-0

Mott JA, Mannino DM, Alverson CJ, Kiyu A, Hashim J, Lee T, Falter K, Redd SC (2005) Cardiorespiratory hospitalizations associated with smoke exposure during the 1997 Southeast Asian forest fires. Intern J Hygiene Environ Health 208:75-85. doi:10.1016/j. ijheh.2005.01.018

Omar NYMJ, Abas MRB, Ketuly KA, Tahir NM (2002) Concentrations of PAHs in atmospheric particles (PM-10) and roadside soil particles collected in Kuala Lumpur, Malaysia. Atmos Environ 36:247-254. doi:10.1016/S1352-2310(01)00425-3

Ozden O, Dogeroglu T, Kara S (2008) Assessment of ambient air quality in Eskișehir, Turkey. Environ Intern 34:678-687. doi:10.1016/j.envint.2007.12.016

Paoletti E (2009) Ozone and urban forests in Italy. Environ Pollut 157:1506-1512. doi:10.1016/j.envpol.2008.09.019

Pereira MC, Santos RC, Alvim-Ferraz MCM (2007) Air quality improvements using European environment policies: a case study of $\mathrm{SO} 2$ in a coastal region in Portugal. J Toxicol Environ Health-Part A: current Issues 70:347-351. doi:10.1080/15287390600884990

Radojevic M, Hassan H (1999) Air quality in Brunei Darussalam during the 1998 haze episode. Atmos Environ 33:3651-3658. doi:10.1016/S1352-2310(99)00118-1

Rashid M, Griffiths RF (1995) Trends of atmospheric fine and coarse particulates in Kuala Lumpur, Malaysia (1986-1990). Environ Technol 16:25-34

Rashid M, Rahmalan A (1993) PM10 lead monitoring in Kuala Lumpur, Malaysia: three years survey. Asian Environ 15:16-21

Rashid Y (1993) PM10 and TSP concentration at two sites of Kuala Lumpur. Asian Environ 15:41-52

Riga-Karandinos A, Saitanis C (2005). Comparative assessment of ambient air quality in two typical Mediterranean coastal cities in Greece. Chemosphere: 1125-1136. doi:10.1016/j.chemosphere. 2004.11.059

Sillman S (1999) The relation between ozone, $\mathrm{NO}(\mathrm{x})$ and hydrocarbons in urban and polluted rural environments. Atmos Environ 33:1821-1845. doi:10.1016/S1352-2310(98)00345-8 